\title{
A Novel Mutation in PIGA Associated with Multiple Congenital Anomalies-Hypotonia-Seizure Syndrome 2 (MCAHS2) in a Boy with a Combination of Severe Epilepsy and Gingival Hyperplasia
}

\author{
Christiane M. Neuhofer ${ }^{a}$ Rudolf Funke ${ }^{b}$ Bernd Wilken ${ }^{b}$ Alexej Knaus ${ }^{c}$ \\ Janine Altmüller ${ }^{d}$ Peter Nürnberg ${ }^{d}$ Yun Li $^{a}$ Bernd Wollnik ${ }^{a}$ Peter Burfeind ${ }^{a}$ \\ Silke Paulia \\ ${ }^{a}$ Institute of Human Genetics, University Medical Center Göttingen, Göttingen, Germany; ${ }^{b}$ Department of Pediatric \\ Neurology, Klinikum Kassel, Kassel, Germany; ' Institute for Genomic Statistics and Bioinformatics, University Hospital

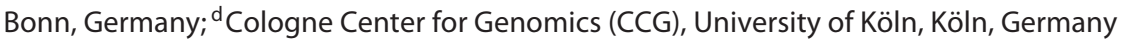

\section{Established Facts}

- Pathogenic mutations in PIGA cause multiple congenital anomalies-hypotonia-seizures syndrome 2 (MCAHS2).

- PIGA codes for an enzyme involved in GPI biosynthesis. Pathogenic mutations in PIGA can disrupt GPI biosynthesis.

\section{Novel Insights}

- The novel variant c.154C>T; p.(His52Tyr) in PIGA causes MCAHS2.

- Flow cytometry analysis for expression of GPI-anchored proteins can facilitate interpretation of unclear variants.

- PIGA-associated disease should be considered in patients presenting with the symptom complex of epilepsy and gingival hyperplasia.

\section{Keywords}

Epilepsy · Epileptic syndromes · GPI-linked proteins .

Phosphatidylinositol glycan class A protein · PIGA

\section{Abstract \\ Multiple congenital anomalies-hypotonia-seizures syn- drome 2 (MCAHS2) is a rare disease caused by mutations in the $\mathrm{X}$ chromosomal PIGA gene. Clinically it is characterized}

by early-onset epilepsy, hypotonia, dysmorphic features, and variable congenital anomalies. PIGA codes for the phosphatidylinositol glycan-class A protein, which forms a subunit of an enzymatic complex involved in glycophosphatidylinositol (GPI) biosynthesis. We present a new case of MCAHS2 and perform a comprehensive review of the available literature to delineate the phenotypical traits associated with germline PIGA mutations. Furthermore, we provide functional evidence of pathogenicity of the novel

\section{KARGER}

(๑) 2020 S. Karger AG, Basel

karger@karger.com www.karger.com/msy
Prof. Dr. Silke Pauli

Institute of Human Genetics, University Medical Center Göttingen Heinrich-Düker-Weg 12

DE-37073 Göttingen (Germany)

spauli@gwdg.de 

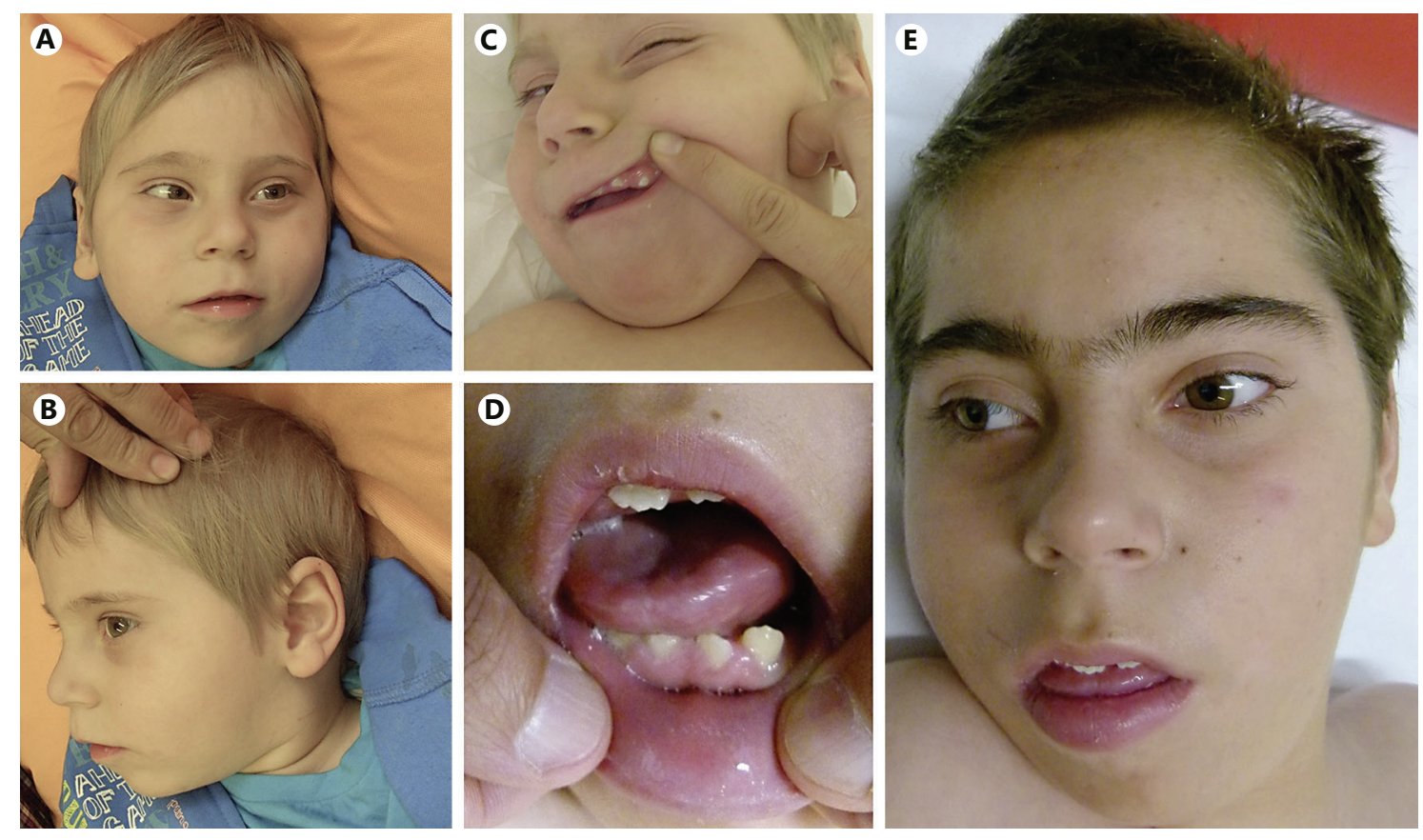

Fig. 1. A-E Facial features of the proband. Patient at 3 years $(\mathbf{A}-\mathbf{C})$ and at 9 years of age (D, E). Upslanting palpebral fissures, short nose with depressed nasal bridge, high anterior hairline, round face, epicanthus, wide mouth, thin upper lip, and short neck are present (A, B). Small, widely spaced teeth and gingival hyperplasia are shown. Pictures were taken after abrasion (C, D). Facial appearance of the boy at the age of 9 years with synophrys (E).

missense mutation, c.154C $>\mathrm{T}$; (p.His52Tyr), in the PIGA gene causative of MCAHS2 in our patient. By flow cytometry, we observed reduced expression of GPI-anchored surface proteins in patient granulocytes compared to control samples, proving GPI-biogenesis impairment. The patient's severe epilepsy with several daily attacks was refractory to treatment, but the frequency of seizures reduced temporarily under triple therapy with perampanel, rufinamide and vigabatrin. Our study delineates the known MCAHS2 phenotype and discusses challenges of diagnosis and clinical management in this complex, rare disease. Furthermore, we present a novel mutation with functional evidence of pathogenicity.

๑) 2020 S. Karger AG, Basel

The PIGA (phosphatidylinositol N-acetylglucosaminyltransferase subunit A) gene codes for a subunit of an enzymatic complex involved in the first step of glycophosphatidylinositol (GPI) biosynthesis [Watanabe et al., 1998]. During posttranslational modification GPI, a glycolipid, can be added to the C-terminus of a protein and allows attachment of the protein to the outer membrane of eukaryotic cells. While somatic PIGA mutations are linked to paroxysmal nocturnal hemoglobinuria (MIM 300818), germline PIGA mutations used to be considered incompatible with life [Keller et al., 1999]. In 2012, Johnston et al. reported the first case of a syndromic form of epilepsy associated with a germline PIGA mutation [Johnston et al., 2012]. The condition, referred to as multiple congenital anomalies-hypotonia-seizures syndrome 2 (MCAHS2; MIM 300868) is characterized by distinct dysmorphic features, neonatal hypotonia, epilepsy, and variable congenital anomalies (Table 1). MCAHS2 follows an X-linked recessive mode of inheritance. To date, more than 40 cases of PIGA-associated MCAHS2 and at least 15 different sequence variants have been described (Table 1) [Johnston et al., 2012; Belet et al., 2014; Kato et al., 2014; Swoboda et al., 2014; van der Crabben et al., 2014; Tarailo-Graovac et al., 2015; Fauth et al., 2016; Joshi et al., 2016; Kim et al., 2016; Trump et al., 2016; Olson et al., 2017; Lin et al., 2018; Low et al., 2018; Yang et al., 2018]. Our report aims to delineate the phenotype of MCAHS2 by presenting the case of a 9 -year-old patient with a previously undescribed hemizygous mutation in the PIGA gene and to provide functional evidence of its pathogenicity. 
Table 1. Signs and symptoms reported in the literature so far with PIGA-associated disease

\begin{tabular}{|c|c|c|c|c|c|c|c|c|}
\hline Reference & $\begin{array}{l}\text { Pedigrees/ } \\
\text { cases }\end{array}$ & Mutations & $\begin{array}{l}\text { Typical } \\
\text { dysmorphic } \\
\text { features }\end{array}$ & $\begin{array}{l}\text { Onset of } \\
\text { epilepsy }\end{array}$ & Brain MRI & $\begin{array}{l}\text { Other } \\
\text { neurological } \\
\text { symptoms }\end{array}$ & Other symptoms & Biochemical \\
\hline Present study & $1 / 1$ & c. $154 \mathrm{C}>\mathrm{T}$; p.(His52Tyr) & + & $8 \mathrm{mo}$ & Normal & $\begin{array}{l}\text { Global } \\
\text { developmental } \\
\text { delay, } \\
\text { developmental } \\
\text { regression, } \\
\text { cerebral visual } \\
\text { impairment, } \\
\text { muscle } \\
\text { hypotonia }\end{array}$ & & \\
\hline $\begin{array}{l}\text { Johnston et al., } \\
2012\end{array}$ & $1 / 3$ & c.1234C>T; (p.Arg412*) & + & & $\begin{array}{l}\text { Thin corpus } \\
\text { callosum, atrophy } \\
\text { of cerebellum, } \\
\text { arhinencephaly, } \\
\text { immature white } \\
\text { matter, septum } \\
\text { pellucidum } \\
\text { agenesis }\end{array}$ & $\begin{array}{l}\text { Muscle } \\
\text { hypotonia, } \\
\text { spasticity }\end{array}$ & $\begin{array}{l}\text { ASD, PDA, VUR, } \\
\text { duplicated } \\
\text { collecting system of } \\
\text { the urinary tract, } \\
\text { hepatic } \\
\text { microvesicular } \\
\text { steatosis, } \\
\text { obstructive apnea }\end{array}$ & eAP \\
\hline $\begin{array}{l}\text { van der Crabben } \\
\text { et al., } 2014\end{array}$ & $1 / 1$ & c.278C>T; p.(Pro93Leu) & + & $8.5 \mathrm{mo}$ & $\begin{array}{l}\text { Thin corpus } \\
\text { callosum, } \\
\text { immature white } \\
\text { matter, cerebral } \\
\text { atrophy }\end{array}$ & $\begin{array}{l}\text { Delay of motor } \\
\text { development, } \\
\text { developmental } \\
\text { regression, } \\
\text { muscle } \\
\text { hypotonia }\end{array}$ & & eAP \\
\hline $\begin{array}{l}\text { Swoboda et al., } \\
2014\end{array}$ & $1 / 3$ & $\begin{array}{l}\text { c.1030_1032delCTT; } \\
\text { p.(Leu344del) }\end{array}$ & + & 7,7 , and $9 \mathrm{mo}$ & $\begin{array}{l}\text { Cerebral and } \\
\text { cerebellar } \\
\text { atrophy }\end{array}$ & $\begin{array}{l}\text { Global } \\
\text { developmental } \\
\text { delay, } \\
\text { developmental } \\
\text { regression, } \\
\text { cerebral visual } \\
\text { impairment, } \\
\text { hearing loss, } \\
\text { tremor, muscle } \\
\text { hypotonia, } \\
\text { spasticity }\end{array}$ & $\begin{array}{l}\text { Hepatomegaly, dry } \\
\text { skin, epidermal } \\
\text { microabscesses }\end{array}$ & Hemochromatosis \\
\hline Belet et al., 2014 & $1 / 5$ & c.76dupT; p.(Tyr26Leufs*3) & NR & $\begin{array}{l}6,5,5,6, \text { and } \\
6 \mathrm{mo}\end{array}$ & $\begin{array}{l}\text { Cerebral and } \\
\text { cerebellar } \\
\text { atrophy }\end{array}$ & $\begin{array}{l}\text { Global } \\
\text { developmental } \\
\text { delay, } \\
\text { developmental } \\
\text { regression, } \\
\text { muscle } \\
\text { hypotonia }\end{array}$ & $\begin{array}{l}\text { Hepatomegaly, } \\
\text { splenomegaly }\end{array}$ & \\
\hline Kato et al., 2014 & $1 / 1$ & c. $1234 \mathrm{C}>\mathrm{T} ; \mathrm{p} .\left(\operatorname{Arg} 412^{*}\right)$ & + & $1 \mathrm{mo}$ & $\begin{array}{l}\text { Thin corpus } \\
\text { callosum, } \\
\text { immature white } \\
\text { matter }\end{array}$ & $\begin{array}{l}\text { Global } \\
\text { developmental } \\
\text { delay, muscle } \\
\text { hypotonia }\end{array}$ & $\begin{array}{l}\text { VUR, } \\
\text { hepatomegaly }\end{array}$ & eAP \\
\hline Kato et al., 2014 & $1 / 1$ & c.616A.T; p.(Ile206Phe) & + & $3 \mathrm{mo}$ & $\begin{array}{l}\text { Thin corpus } \\
\text { callosum, } \\
\text { immature white } \\
\text { matter }\end{array}$ & $\begin{array}{l}\text { Global } \\
\text { developmental } \\
\text { delay, spasticity }\end{array}$ & VUR & eAP \\
\hline Kato et al., 2014 & $1 / 2$ & c.230G.T; p.(Arg77Leu) & - & $7 \mathrm{mo}, 7 \mathrm{mo}$ & Normal & $\begin{array}{l}\text { Delay of } \\
\text { psychomotor } \\
\text { and speech } \\
\text { development }\end{array}$ & & \\
\hline Kato et al., 2014 & $1 / 1$ & c.355C.T; p.(Arg119Trp) & + & $3 \mathrm{mo}$ & $\begin{array}{l}\text { Thin corpus } \\
\text { callosum, } \\
\text { immature white } \\
\text { matter }\end{array}$ & $\begin{array}{l}\text { Global } \\
\text { developmental } \\
\text { delay, muscle } \\
\text { hypotonia, } \\
\text { spasticity }\end{array}$ & & eAP \\
\hline $\begin{array}{l}\text { Tarailo-Graovac } \\
\text { et al., } 2015\end{array}$ & $1 / 1$ & c. $989 \mathrm{G}>$ A; p.(Ser330Asn) & + & $2.4 \mathrm{mo}$ & $\begin{array}{l}\text { Thin corpus } \\
\text { callosum, } \\
\text { cerebral and } \\
\text { cerebellar } \\
\text { atrophy, } \\
\text { immature white } \\
\text { matter }\end{array}$ & $\begin{array}{l}\text { Global } \\
\text { developmental } \\
\text { delay, hearing } \\
\text { loss, muscle } \\
\text { hypotonia, } \\
\text { spasticity }\end{array}$ & $\begin{array}{l}\text { Right ventricular } \\
\text { hypertrophy, } \\
\text { Wenckebach type } \\
\text { AV block, } \\
\text { hydronephrosis, } \\
\text { hepatomegaly }\end{array}$ & $\begin{array}{l}\text { eAP, } \\
\text { hypertriglyceridemia, } \\
\text { hypercholesterolemia, } \\
\text { LPL deficiency }\end{array}$ \\
\hline
\end{tabular}


Table 1 (continued)

\begin{tabular}{|c|c|c|c|c|c|c|c|c|}
\hline Reference & $\begin{array}{l}\text { Pedigrees/ } \\
\text { cases }\end{array}$ & Mutations & $\begin{array}{l}\text { Typical } \\
\text { dysmorphic } \\
\text { features }\end{array}$ & $\begin{array}{l}\text { Onset of } \\
\text { epilepsy }\end{array}$ & Brain MRI & $\begin{array}{l}\text { Other } \\
\text { neurological } \\
\text { symptoms }\end{array}$ & Other symptoms & Biochemical \\
\hline Fauth et al., 2016 & $3 / 6$ & c.1234C>T; p.(Arg412*) & + & & $\begin{array}{l}\text { Immature white } \\
\text { matter, atrophy } \\
\text { of cerebellum }\end{array}$ & $\begin{array}{l}\text { Muscle } \\
\text { hypotonia }\end{array}$ & $\begin{array}{l}\text { PFO, ASD, } \\
\text { hydronephrosis, } \\
\text { dysplastic kidneys, } \\
\text { hepatomegaly, } \\
\text { splenomegaly }\end{array}$ & eAP \\
\hline $\begin{array}{l}\text { Trump et al., } \\
2016\end{array}$ & $1 / 1$ & c.1064T>C; p.(Leu355Ser) & NR & $5 \mathrm{mo}$ & $\begin{array}{l}\text { Thin corpus } \\
\text { callosum }\end{array}$ & & & \\
\hline Joshi et al., 2016 & $1 / 2$ & c.A535T; p.(Asn179Tyr) & NR & $6 \mathrm{mo}, 4 \mathrm{mo}$ & & $\begin{array}{l}\text { Global } \\
\text { developmental } \\
\text { delay, muscle } \\
\text { hypotonia }\end{array}$ & & \\
\hline Kim et al., 2016 & $1 / 1$ & c. $427 \mathrm{~A}>\mathrm{G}$; p.(Lys143Glu) & NR & $5 \mathrm{mo}$ & $\begin{array}{l}\text { Hippocampal } \\
\text { sclerosis }\end{array}$ & $\begin{array}{l}\text { Global } \\
\text { developmental } \\
\text { delay, } \\
\text { developmental } \\
\text { regression }\end{array}$ & & \\
\hline Olson et al., 2017 & $1 / 1$ & c.424G>A; p.(Ala142Thr) & NR & $10 \mathrm{~d}$ & $\begin{array}{l}\text { Thin corpus } \\
\text { callosum }\end{array}$ & $\begin{array}{l}\text { Choreatic } \\
\text { movement, } \\
\text { tremor }\end{array}$ & & \\
\hline Low et al., 2018 & $1 / 1$ & c.293A>C; p.(Tyr98Ser) & - & $4 \mathrm{mo}$ & $\begin{array}{l}\text { Myelination } \\
\text { defects }\end{array}$ & $\begin{array}{l}\text { Global } \\
\text { developmental } \\
\text { delay, } \\
\text { developmental } \\
\text { regression, } \\
\text { choreatic } \\
\text { movement }\end{array}$ & Sleep apnea & \\
\hline Yang et al., 2018 & $1 / 5$ & c.849-5A>G; p.(Arg283Serfs*15) & + & $29 \mathrm{~d}$ to $10 \mathrm{mo}$ & & $\begin{array}{l}\text { Global } \\
\text { developmental } \\
\text { delay, muscle } \\
\text { hypotonia }\end{array}$ & & \\
\hline Lin et al., 2018 & $1 / 3$ & c.356G >A; p.(Arg119Gln) & + & $\begin{array}{l}\text { unknown } \\
\text { (deceased at } \\
\text { age } 2 \text { mo), } \\
\text { unknown } \\
\text { (deceased at } \\
\text { age } 2 \text { mo) }\end{array}$ & $\begin{array}{l}\text { Cerebral atrophy, } \\
\text { thin corpus } \\
\text { callosum, delayed } \\
\text { myelination }\end{array}$ & $\begin{array}{l}\text { Muscle } \\
\text { hypotonia, } \\
\text { dysykinesia, } \\
\text { dystonia, } \\
\text { choreatic } \\
\text { movement }\end{array}$ & $\begin{array}{l}\text { Bilateral } \\
\text { hydronephrosis }\end{array}$ & eAP \\
\hline
\end{tabular}

ASD, atrial septum defect; d, days; eAP, elevated alcalic phosphatase; mo, months; NR, not reported; PDA, persisting ductus arteriosus; PFO, persisting foramen ovale; VUR, vesicoureteral reflux.

\section{Case Report}

The male patient was born at term as the first child of healthy nonconsanguineous parents with a birth weight of 3,220 $\mathrm{g}$ (P42), length of $50 \mathrm{~cm}$ (P32), and a head circumference of $34.5 \mathrm{~cm}$ (P39). At the age of 8 months, the boy suffered a first focal cerebral seizure lasting $15 \mathrm{~min}$. Thereafter, he developed an epileptic encephalopathy with daily seizures refractory to treatment. He presented different seizure types, including generalized tonic-clonic seizures, myoclonus, and tonic seizures with initial eye deviation. Temporary stabilization with a reduced seizure frequency of about 3 episodes per day was achieved with a triple therapy including perampanel, rufinamide, and vigabatrin. The onset of symptomatic epilepsy was accompanied by an arrest and regression of psychomotor development, with loss of previously learned skills, such as sitting upright, or usage of the hands. From the age of 3 years, he suffered recurrent episodes of status epilepticus, which were treated with diazepam or lorazepam in combination with glucocorticoids. Brain MRI diagnostics at the age of $11 / 12$ and $32 / 12$ years showed a slight widening of the cerebrospinal fluid spaces, but no major brain malformations or anomalies. Alkaline phosphatase (AP) levels were measured repeatedly and yielded normal results [e.g., at 8 months of age $367 \mathrm{U} / \mathrm{L}$ (norm <462) and at age $36 / 12$ years, 212 U/L (norm <269)]. Of interest, the boy had wide-spaced small teeth and pronounced gingival hyperplasia, recurrent after abrasion (Fig. 1). At the current age of 9 years, the boy lacks head control and cannot sit or use his hands. He has never developed active use of speech. Dysmorphic traits include upslanting eyes, a long philtrum, and a thin upper lip. The patient has cerebral visual impairment, bilateral strabismus, hyperkyphosis and secondary microcephaly, dropping below the first percentile with a head circumference last measured at $48 \mathrm{~cm}(<\mathrm{P} 1)$ at the age of 5 years and 3 months. Family history was unremarkable for miscarriage, intellectual disability, epilepsy, or other malformations. 
Fig. 2. GPI-anchored protein marker expressions as measured with flow cytometry. A Histograms depicting median fluorescence intensity (MFI) representing markers stained in patient and control granulocytes (parents and healthy unrelated control) - CD59, CD55, CD16, FLAER, CD16b, and CD24 - showing a reduced MFI for CD16, FLAER, CD16b, and CD24 in the patient as compared to the controls (top). Gating strategy for flow cytometry analysis for granulocytes from peripheral blood samples of the patient, his parents, and a healthy unrelated control. Cells were first gated for granular cells (FSC vs. SSC), CD45 positive cells (SSC-A vs. CD45PacBlue-A), and finally singlets (FSC-H vs. FSC-A) (bottom). B Relative marker expression of the index patient and his mother as compared to his father and control $(=1)$ calculated by the ratio of MFI of patient and mother to father and healthy unrelated control. CD16, FLAER, CD16b, and CD24 expression appear reduced in comparison to the father and healthy control in the patient. CD16 and CD24 expression also appear reduced in the mother as compared to the father and healthy control.
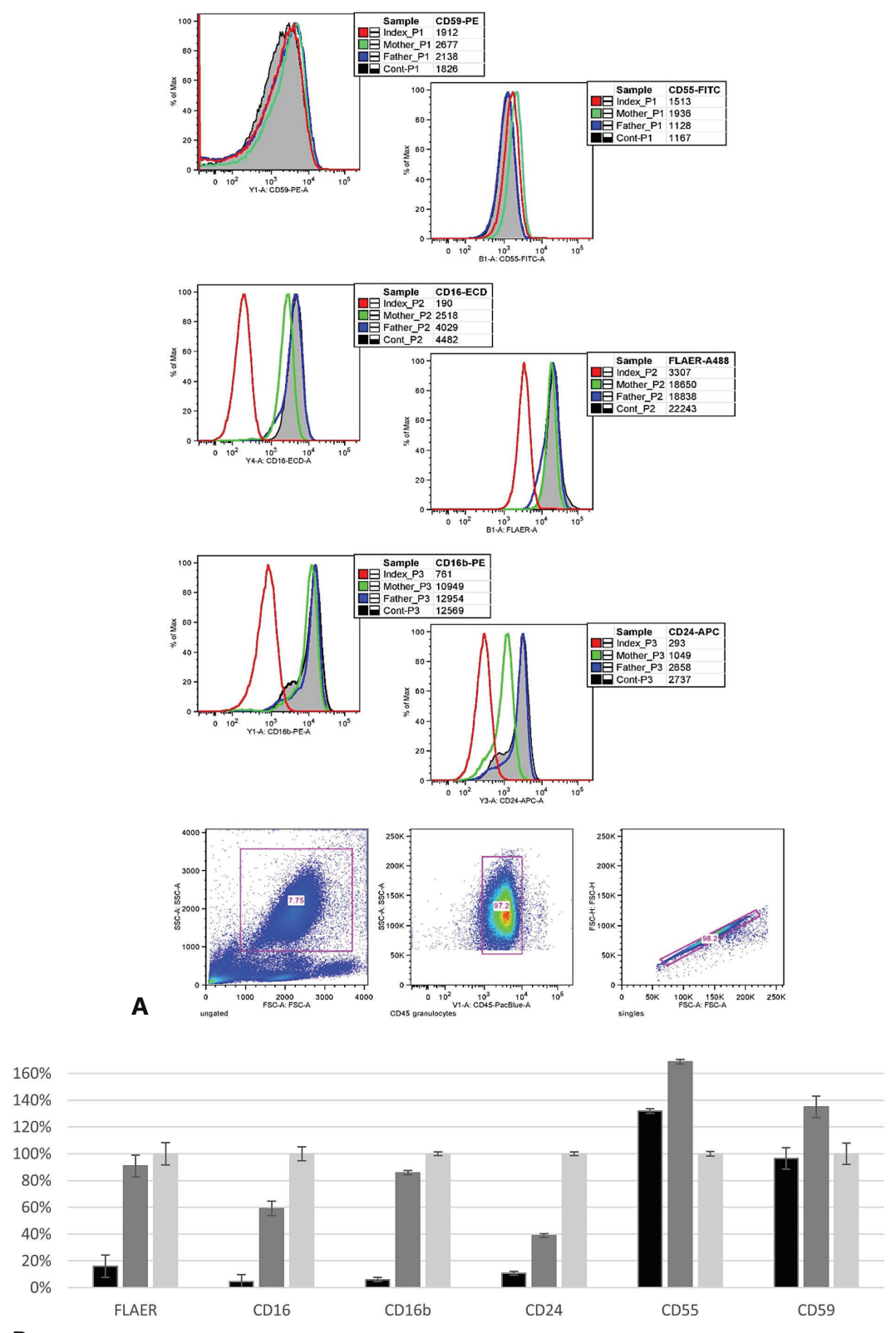

B

\section{Materials and Methods}

Since routine cytogenetic and molecular genetic diagnostics failed to elucidate the cause of the patient's disease, we performed trio whole-exome sequencing (WES).

\section{Trio Exome Sequencing}

We performed WES on blood DNA samples of the patient and his healthy parents using Agilent SureSelect Human All Exon V6 r2 kit on an Illumina HiSeq4000 sequencer. The "Varbank" pipeline of the Cologne Center for Genomics (CCG) was used to analyze the exome data employing the filter criteria: coverage of $>6$ reads, quality score of $>10$, allele frequency $\geq 25 \%$, and a minor allele frequency $<0.1 \%$ in the 1000 Genomes database and the Exome Variant Server (EVS; NHLBI Exome Sequencing Project). The results were analyzed by the multidisciplinary NGS-data-analysis team (Mutation Mining (MM)-Team) of the Institute of Human Genetics, University Medical Center Göttingen, comprising 28 members with different backgrounds.

\section{Flow Cytometry}

Peripheral blood leukocytes of the patient, both parents, and an unrelated healthy control were analyzed by flow cytometry. $50 \mu \mathrm{L}$ whole blood was incubated for $30 \mathrm{~min}$ at room temperature with 
antibodies against CD45-PacBlue (leukocyte marker), CD16ECD, CD16b-PE, CD24-APC, CD55-FITC, CD59-PE, and FLAER (fluorescein-labeled proaerolysin). Erythrocytes were removed with a lysis buffer and the cells washed twice with FACS buffer. Samples were analyzed on a MACS-Quant VYB (Miltenyi Biotec); gating and data analysis was done with Flow $\mathrm{Jo}^{\mathrm{TM}}$ v. 9.9.6 software. Granular cells were gated using forward and side scatter (FSC vs. SSC). Single cells were gated on the diagonal of the FSC-H (forward scatter height) versus FSC-A (forward scatter area) of CD45 positive granulocytes. Gating strategy and histograms of marker expression are depicted in Figure 2A.

\section{Results}

Using trio WES and subsequent Sanger sequencing, we detected no de novo, homozygous, or compound heterozygous candidate mutations in our patient. Analysis yielded 7 hemizygous variants in the genes SLC6A8, PASD1, BCORL1, P2RY4, CCDC120, SSX3, and PIGA. The hemizygous missense variant c.154C $>\mathrm{T}$ in exon 2 of the PIGA gene, leading to an amino acid exchange from histidine to tyrosine at position 52 (p.His52Tyr), was identified as a likely causative candidate as it was a known disease gene associated with a phenotype matching to our patient. In silico prediction unanimously considered the variant likely deleterious (PolyPhen-2: probably damaging, SIFT: damaging, PROVEAN: deleterious, Mutation Taster: disease causing, and M-CAP: possibly pathogenic). We confirmed the heterozygous state of the variant in the patient's mother, and identified a wildtype sequence in the father. The variant in the PIGA gene was not listed in the ExAC, gnom $\mathrm{AD}$, or $\mathrm{HGMD}^{\circledR}$ databases, and to our knowledge, it has not been previously reported in scientific literature. The affected amino acid (p.His52) in the PIGA protein appears to be highly conserved, further supporting the putative pathogenicity of this variant.

To confirm the diagnosis of a PIGA-associated disorder affecting GPI anchor biosynthesis, protein levels of the GPI-anchored marker proteins CD16, CD16b, CD24, CD59, CD55, and FLAER were analyzed in the blood cells of the patient, his parents, and a healthy control by flow cytometry. Previous studies have suggested a reduced expression profile of GPI-anchored proteins in patients with GPI biosynthesis defects, such as PIGA-associated disorders [Zhao et al., 2017; Knaus et al., 2018].

Analysis of protein levels of GPI-anchored proteins in granulocytes of our patient showed a reduced expression of CD16, CD16b, CD24, and FLAER in patient granulocytes compared to the healthy father and an unrelated healthy control, which is consistent with reduced GPI biosynthesis (Fig. 2B). The patient's asymptomatic moth- er also showed a reduction of CD24 and CD16 expression of about $50 \%$ in comparison to the father and a healthy control.

\section{Discussion}

To our knowledge, more than 40 cases of MCAHS2 have been reported to date (Table 1) and at least 15 different mutations have been described. The most frequent observed mutation was c.1234C>T (p.Arg412*), reported in 10 cases. A common feature in all cases described was early-onset epilepsy, with first seizures reported from the neonatal period to the age of 10 months. Focal seizures in our patient occurred at 8 months of age, and he developed progressive epileptic encephalopathy.

Onset of epilepsy is commonly reported to be accompanied by delay, arrest, or even regression of psychomotor development in MCAHS2 patients. Our patient first showed developmental regression at the age of 8 months.

PIGA-associated epilepsy appears to be difficult to manage and is often reported as refractory to treatment. However, there were 2 reports of successful treatment in affected children. Kato et al. [2014] reported 2 mild cases of MCAHS2 due to a missense mutation, c.230G $>$ T (p. R77L), with moderate intellectual disability, but normal motor development, one brother being seizure free without treatment since the age of 15 months, the other being seizure free under topiramate treatment. Joshi et al. [2016] described a successful treatment with ketogenic diet in 2 brothers carrying the missense mutation c.535A $>\mathrm{T}$ ( $\mathrm{p}$. $\mathrm{N} 179 Y$ ), resulting in cessation of seizures in both children and stabilizing development in the child treated early, from the age of 10 months. Seizures reportedly restarted upon interruption of the ketogenic diet, prompting the decision of the parents to keep both boys on a ketogenic diet permanently. The treated brothers remained seizure free at the age of 6 and 8 years, respectively, and even though both children suffered severe psychomotor impairment, the younger child showed better motor development than the older brother [Joshi et al., 2016]. These recent findings suggest ketogenic diet as a promising treatment option in young patients affected by PIGA-associated epileptic encephalopathy and may hint towards a critical therapeutic window in an early stage of the disease. Our patient receives a combination treatment of perampanel, rufinamide, and vigabatrin, which resulted in significant improvement of quality of life by reducing seizure frequency to about 3 episodes daily. Recently, however, the patient's symptoms deteriorated with in- 
creased frequency of epileptic attacks, status epilepticus, and a comatose episode.

A recurrent biochemical finding in previous reports of MCAHS2 was the elevation of AP. Murakami et al. [2012] suggested a functional link of an AP elevation to defects affecting the early steps of GPI biosynthesis. To some extent AP may be considered a biomarker for diseases such as PIGA-associated MCAHS2; however, it is of note that an increase of AP was not detectable in all cases, including the patient we present in this study. Our patients AP value was tested and reported as normal on several occasions. This observation prompts caution concerning AP as a biomarker; normal AP levels cannot exclude GPI biosynthesis defects as possible disease cause in a given case and should be interpreted carefully.

Previous reports consistently described dysmorphic traits in MCAHS2 patients, showing a typical facies associated with the disease, which however appears to be minimal or absent in mild cases. Frequent features are a small triangular mouth with downturned corners, a thin upper lip, a short nose with a depressed nasal bridge and anteverted nares, tooth anomalies, and upslanting palpebral fissures. Gingival hyperplasia, as observed in our patient, has been reported in 6 patients with MCAHS2 in literature so far. As an additional feature, our patient developed synophrys (Fig. 1) and pronounced secondary microcephaly, dropping from the 39th percentile at birth beneath the 1st percentile upon the last reported measurement at the age of $53 / 12$ years.

Symptoms in other organ systems in MCAHS2 have been described to a variable degree and inconsistently (Table 1), although anomalies of the heart, urinary tract, and hepatosplenomegaly seem to be recurrent. Our patient did not present any anomalies of inner organs. He also did not show distinct brain anomalies.

Reported causes of death in affected patients frequently involve infections and respiratory failure. Recurrent respiratory infections and recurrent aspiration due to muscular hypotonia were present in our patient, and repeatedly warranted medical attention. A majority of the patients has been reported to pass away within the first decade, although overall the reported lifespan ranges from 1 month in a severe case to 21 years in a mild case. To date, a clear genotype-phenotype correlation could not be observed.

Flow cytometry analysis showed a reduced expression of several GPI-anchored proteins in patient granulocytes as compared to a healthy control and the asymptomatic father, consistent with a GPI-anchored protein defect. However, we also observed a mild reduction of CD24 and
CD16 expression in the patient's mother. This could be explained by the heterozygous carrier status of the mother and random $\mathrm{X}$ inactivation. Flow cytometry analysis of patients suspected for GPI biosynthesis defects should therefore be performed with healthy (noncarrier) controls in addition to the parents.

In conclusion, our case report delineates the known phenotype of MCAHS2 and presents a novel mutation in $P I G A$ with functional evidence of its pathogenicity. In patients showing the symptom complex of epilepsy and gingival hyperplasia, PIGA-associated disease should be considered. Further studies are needed to better understand this rare disease and evaluate management and treatment options with the goal to provide access to the best clinical care for MCAHS2 patients.

\section{Acknowledgments}

We are grateful to the patient and his family for their participation in this study. We also thank Karin Boss for critically reading the manuscript.

\section{Statement of Ethics}

Informed consent was obtained from the patient's parents. The present study was approved by the Ethics Committee of the Faculty of Medicine, University of Göttingen (file No. 3/2/15).

\section{Disclosure Statement}

The authors have no conflicts of interest to declare.

\section{Author Contributions}

C. Neuhofer provided clinical data and wrote the manuscript. S. Pauli, R. Funke, and B. Wilken provided clinical data. A. Knaus performed functional testing. J. Altmüller, P. Nürnberg, Y. Li, B. Wollnik, and P. Burfeind provided molecular genetic data, and S. Pauli, B. Wollnik, and P. Burfeind supervised the study.

References

\footnotetext{
Belet S, Fieremans N, Yuan X, Van Esch H, Verbeeck J, et al: Early frameshift mutation in PIGA identified in a large XLID family without neonatal lethality. Hum Mutat 35:350355 (2014)

Fauth C, Steindl K, Toutain A, Farrell S, WitschBaumgartner $\mathrm{M}$, et al: A recurrent germline mutation in the PIGA gene causes SimpsonGolabi-Behmel syndrome type 2. Am J Med Genet A 170A:392-402 (2016).
}

Neuhofer et al. 
-Johnston JJ, Gropman AL, Sapp JC, Teer JK, Martin JM, et al: The phenotype of a germline mutation in PIGA: the gene somatically mutated in paroxysmal nocturnal hemoglobinuria. Am J Hum Genet 90:295-300 (2012).

Joshi C, Kolbe DL, Mansilla MA, Mason S, Smith RJ, et al: Ketogenic diet - A novel treatment for early epileptic encephalopathy due to PIGA deficiency. Brain Dev 38:848-851 (2016).

Kato M, Saitsu H, Murakami Y, Kikuchi K, Watanabe S, et al: PIGA mutations cause early-onset epileptic encephalopathies and distinctive features. Neurology 82:1587-1596 (2014).

Keller P, Tremml G, Rosti V, Bessler M: X inactivation and somatic cell selection rescue female mice carrying a Piga-null mutation. Proc Natl Acad Sci USA 96:7479-7483 (1999).

-Kim YO, Yang JH, Park C, Kim SK, Kim MK, et al: A novel PIGA mutation in a family with Xlinked, early-onset epileptic encephalopathy. Brain Dev 38:750-754 (2016).

Knaus A, Pantel JT, Pendziwiat M, Hajjir N, Zhao $\mathrm{M}$, et al: Characterization of glycosylphosphatidylinositol biosynthesis defects by clinical features, flow cytometry, and automated image analysis. Genome Med 10:3 (2018).

Lin WD, Chou IC, Tsai FJ, Hong SY: A novel PIGA mutation in a Taiwanese family with early-onset epileptic encephalopathy. Seizure 58:52-54 (2018)

Low KJ, James M, Sharples PM, Eaton M, Jenkinson S, et al: A novel PIGA variant associated with severe X-linked epilepsy and profound developmental delay. Seizure 56:1-3 (2018).

Murakami Y, Kanzawa N, Saito K, Krawitz PM, Mundlos S, et al: Mechanism for release of alkaline phosphatase caused by glycosylphosphatidylinositol deficiency in patients with hyperphosphatasia mental retardation syndrome. J Biol Chem 287:6318-6325 (2012).

Olson HE, Kelly M, LaCoursiere CM, Pinsky R, Tambunan D, et al: Genetics and genotypephenotype correlations in early onset epileptic encephalopathy with burst suppression. Ann Neurol 81:419-429 (2017).

-Swoboda KJ, Margraf RL, Carey JC, Zhou H, Newcomb TM, et al: A novel germline PIGA mutation in Ferro-Cerebro-Cutaneous syndrome: a neurodegenerative X-linked epileptic encephalopathy with systemic iron-overload. Am J Med Genet A 164A:17-28 (2014).

Tarailo-Graovac M, Sinclair G, Stockler-Ipsiroglu S, Van Allen M, Rozmus J, et al: The genotypic and phenotypic spectrum of PIGA deficiency. Orphanet J Rare Dis 10:23 (2015).

Trump N, McTague A, Brittain H, Papandreou A, Meyer E, et al: Improving diagnosis and broadening the phenotypes in early-onset seizure and severe developmental delay disorders through gene panel analysis. J Med Genet 53:310-317 (2016).

van der Crabben SN, Harakalova M, Brilstra EH, van Berkestijn FM, Hofstede FC, et al: Expanding the spectrum of phenotypes associated with germline PIGA mutations: a child with developmental delay, accelerated linear growth, facial dysmorphisms, elevated alkaline phosphatase, and progressive CNS abnormalities. Am J Med Genet A 164A:29-35 (2014).

Watanabe R, Inoue N, Westfall B, Taron CH, Orlean $\mathrm{P}$, et al: The first step of glycosylphosphatidylinositol biosynthesis is mediated by a complex of PIG-A, PIG-H, PIG-C, and GPI1. EMBO J 17:877-885 (1998).

- Yang J, Wang Q, Zhuo Q, Tian H, Li W, et al: A likely pathogenic variant putatively affecting splicing of PIGA identified in a multiple congenital anomalies hypotonia-seizures syndrome 2 (MCAHS2) family pedigree via whole-exome sequencing. Mol Genet Genomic Med 6:739-748 (2018).

Zhao JJ, Halvardson J, Knaus A, Georgii-Hemming $\mathrm{P}$, Baeck $\mathrm{P}$, et al: Reduced cell surface levels of GPI-linked markers in a new case with PIGG loss of function. Hum Mutat 38: 1394-1401 (2017). 